\title{
Optimalisasi Lahan Pekarangan Sebagai Salah Satu Upaya Pencegahan Krisis Pangan di Masa Pandemi Covid-19
}

\author{
Optimization Of Backyard Land As One Of The Efforts To Prevent Food Crisis \\ In The Covid-19 Pandemic \\ Ardli Swardana \\ Program Studi Agroteknologi Fakultas Pertanian Universitas Garut \\ Jl. Raya Samarang No.52A, Tarogong Kaler, Kabupaten Garut, Jawa Barat 44151 \\ e-mail : ardli@uniga.ac.id
}

\begin{abstract}
ABSTRAK
Saat ini dunia sedang mengalami wabah COVID-19. Adanya wabah ini menyebabkan beberapa wilayah menetapkan kebijakan karantina wilayah. Dampak yang ditimbulkan dari adanya kebijakan ini adalah dapat menimbulkan krisis pangan. Salah satu usaha yang dapat dilakukan untuk mencegah terjadinya krisis pangan adalah kegiatan optimalisasi pekarangan. Kegiatan ini mempunyai banyak manfaat, diantaranya pemenuhan kebutuhan rumah tangga dan peningkatan ekonomi keluarga. Kegiatan optimalisasi pekarangan dapat dilakukan dengan cara melakukan kegiatan KRPL sesuai arahan dari Kementerian Pertanian maupun kegiatan optimalisasi pekarangan secara tradisional.
\end{abstract}

Kata Kunci : COVID-19, krisis pangan, optimalisasi pekarangan

\begin{abstract}
The world is currently experiencing a pandemic of COVID-19. This condition caused several regions to establish a quarantine policy for the region. The impact of this policy is that it can cause a food crisis. One effort that can be done to prevent a food crisis is the backyard optimization activity. This activity has many benefits, including fulfillment of household needs and improving the family's economy. The backyard optimization activity can be carried out by conducting KRPL activities according to the direction of the Ministry of Agriculture and traditional yard optimization activities.
\end{abstract}

Keywords: COVID-19, food crisis, Optimization Of Backyard

\section{PENDAHULUAN}

COVID-19 yang dinyatakan menjadi pandemi di dunia oleh WHO (WHO, 2020) merupakan salah satu famili virus yang menyerang manusia, yaitu menyerang saluran pernapasan manusia (Ramadayanti, 2020). Awal mula virus ini diketahui menyebar di Kota Wuhan, Republik Rakyat Tiongkok sejak 
Desember 2019 (Heldavidson, 2020), kemudian diberi nama Severe Acute Respiration Syndrome Coronavirus 2 (SARS-COV2) dan menyebabkan penyakit Coronavirus Disease-2019/COVID-19 (Safrizal et.al. 2020). Keberadaan virus ini cepat sekali penyebarannya secara global dan bersifat sangat menular. Dalam pertemuan tanggal 30 Januari 2020, sesuai dengan Peraturan Kesehatan Internasional, WHO menetapkan COVID-19 sebagai Public Health Emergency of International Concern (PHEIC)/Kedaruratan Kesehatan Masyarakat yang Meresahkan Dunia (KKMMD) wabah pandemi karena telah menyebar ke 18 negara dengan 4 negara melaporkan transmisi ke manusia.

Sampai saat ini, wabah ini terus meningkat angka epidemi nya. Pada 16 Februari 2020, dilaporkan telah terjadi 51.857 kasus konfirmasi di 25 negara dengan 1.669 kematian (WHO, 2020). Berdasarkan data per 18 Mei dari Dashboard Darurat Kesehatan WHO, telah dilaporkan total 4.628.903 kasus yang dikonfirmasi, 312.009 kasus kematian yang tersebar di 216 negara. di seluruh dunia sejak awal epidemi.

Salah satu negara yang terkena wabah pandemi COVID-19 adalah Indonesia. Presiden Joko Widodo mengumumkan kasus COVID-19 pertama di Indonesia pada tanggal 2 Maret 2020, yaitu dua warga negara Indonesia dinyatakan positif COVID-19 setelah melakukan kontak dengan warna negara Jepang yang datang ke Indonesia (Baskara, 2020). Hingga 19 Mei 2020, jumlah angka terkonfirmasi di Indonesia adalah 18.010 orang, meninggal dunia 1.191 orang dan sembuh 4.324 orang (Gugus Tugas Percepatan Penanganan COVID-19, 2020).

Melihat cepatnya dan banyaknya kasus yang setiap hari mengalami kenaikan, maka di beberapa wilayah telah diberlakukan karantina wilayah. Efek dari karantina wilayah lebih lanjut dapat menyebabkan terjadinya krisis pangan. Hal ini dapat terjadi dikarenakan adanya pembatasan jalur perdagangan oleh negara produsen (eksportir) kepada negara konsumen (importir). Contoh negara yang menetapkan kebijakan pembatasan perdagangan ini adalah Vietnam yang membatasi jalur perdagangan beras. Selama ini Vietnam merupakan negera pengekspor utama beras. Vietnam menetapkan kebijakan menghentikan ekspor beras dan memenuhi kebutuhan domestik negaranya. Jika hal ini terjadi dan 
diikuti negara eksportir makanan lainnya, maka pasokan pangan lintas negara akan terganggu dan dapat menyebabkan krisis pangan di negara importir, salah satunya adalah Indonesia yang melakukan impor beras dari Vietnam (Khudori, 2020).

Presiden Joko Widodo mengakui ketersediaan bahan pangan di sejumlah wilayah mengalami defisit pangan akibat kegiatan karantina wilayah dan pembatasan perdagangan negara. Menurut Jayani (2020), penyebab masalah pangan dari pembatasan ekspor beras dari beberapa negara ke Indonesia antara lain Vietnam (memasok 9,01\% beras impor tahun 2019), India (memasok 1,6\% beras impor tahun 2019) dan Thailand (memasok 20,9 \% beras impor 2019). Selain itu, penyebab masalah pangan ini juga disebabkan oleh pergeseran musim tanam, persoalan cuaca di beberapa daerah, dan kelancaran distribusi pupuk.

Salah satu kegiatan yang dapat dilakukan untuk mencegah terjadinya krisis pangan adalah dengan melakukan diversifikasi makanan dan tidak mengandalkan sepenuhnya pada jumlah pangan yang ada di pasaran. Cara yang dapat dilakukan agar tidak mengandalkan sepenuhnya pada jumlah pangan yang ada di pasaran adalah dengan melakukan kegiatan optimalisasi pekarangan. Tulisan ini bertujuan untuk mengulas tentang cara kegiatan optimalisasi pekarangan dan model pertanian pekarangan yang dapat dilakukan di masa pandemic COVID-19.

\section{PEMBAHASAN}

Pekarangan merupakan sebidang tanah yang mempunyai batas-batas tertentu yang di atasnya terdapat bangunan untuk tempat tinggal/rumah serta mempunyai hubungan fungsional, baik ekonomi, biofisik, maupun sosial budaya dengan pemiliknya (Soemarwoto, 1981). Affandi (2002), mendefinisikan pekarangan sebagai sistem usaha tani tradisional yang di dalamnya berisi perpaduan tanaman tahunan dan tanaman pangan semusim yang berada di sekitar rumah masyarakat.

Definisi pekarangan sebagai usaha tani berimplikasi pada fungsi pekarangan itu sendiri. Danoesastro et. al. (1979) dalam Irwan et. al. (2018) mengemukakan fungsi dari pekarangan, antara lain sebagai penghasil bahan makanan, penghasil rempah atau obat, penghasil kayu bakar, penghasil bahan bangunan, dan bahan baku kerajinan. Berdasarkan fungsi ini pekarangan dapat 
diterapkan untuk memenuhi kebutuhan rumah tangga. Rumah tangga yang mampu mengelola pekarangan dengan baik, selain dapat memenuhi kebutuhan rumah tangganya, tentunya dapat juga untuk meningkatkan ekonomi rumah tangganya yang berasal dari penjualan hasil dari pekarangan.

Kondisi saat ini dari pekrangan masih banyak masyarakat yang belum memanfaatkan pekarangan dan membiarkan pekarangannya ditumbuhi rumput dan belukar. Masyarakat belum sadar akan potensi pekarangan yang begitu besar. Pemanfaatan pekarangan biasanya hanya sebagai sambilan atau mengisi waktu luang saja. Dengan kata lain, pengelolaan pekarangan belum dilakukan dengan optimal.

Dilihat dari pentingnya peran pekarangan dalam memenuhi kebutuhan masyarakat dalam hal pangan, maka terdapat program dari Kementerian Pertanian dengan menyusun konsep Kawasan Rumah Pangan Lestari (KRPL). Konsep ini pada dasarnya mendorong suatu rumah tangga untuk dapat melakukan kemandirian pangan melalui pemanfaatan pekarangan. KRPL ini mengusung konsep pedesaan dan perkotaan. Hal ini dikarenakan konsep pemanfaatan pekarangan ini tidak hanya bisa dilakukan di desa saja yang mempunyai banyak lahan kosong. Lahan perkotaan yang tidak mempunyai halaman pun, diatur desain atau model yang sesuai dengan kondisinya. Tabel 1 menunjukkan desain atau model dari budidaya rumah tangga berserta jenis komoditas di pekarangan perkotaan.

Tabel 1. Basis komoditas dan contoh model budidaya Rumah Pangan Lestari menurut kelompok pekarangan perkotaan

\begin{tabular}{|c|c|c|c|c|}
\hline No & $\begin{array}{l}\text { Kelompok } \\
\text { lahan }\end{array}$ & Model Budidaya & \multicolumn{2}{|c|}{ Basis Komoditas } \\
\hline \multirow[t]{3}{*}{1} & $\begin{array}{l}\text { Rumah } \\
\text { Tipe } 21 \\
\text { (Luas } \\
\text { tanah } \\
\text { sekitar } 36\end{array}$ & $\begin{array}{l}\text { Vertikultur (model } \\
\text { gantung, tempel, } \\
\text { tegak, rak) }\end{array}$ & Sayuran: & $\begin{array}{l}\text { Sawi, kucai, pakcoi, } \\
\text { kangkung, bayam, } \\
\text { kemangi, caisim, } \\
\text { seledri, selada bokor, } \\
\text { bawang daun }\end{array}$ \\
\hline & $\begin{array}{l}\text { m2), tanpa } \\
\text { halaman }\end{array}$ & & Toga: & $\begin{array}{l}\text { Kencur, antanan, } \\
\text { gempur batu, daun } \\
\text { jinten, sambiloto, jahe } \\
\text { merah, binahong, } \\
\text { sirih }\end{array}$ \\
\hline & & $\begin{array}{l}\text { Pot/polibag } \\
\text { benih/bibit }\end{array}$ & Sayuran: & $\begin{array}{l}\text { Cabai, terong, tomat, } \\
\text { buncis tegak }\end{array}$ \\
\hline
\end{tabular}




\begin{tabular}{|c|c|c|c|c|}
\hline \multirow[t]{2}{*}{ No } & \multirow[t]{2}{*}{$\begin{array}{l}\text { Kelompok } \\
\text { lahan }\end{array}$} & \multirow[t]{2}{*}{ Model Budidaya } & \multicolumn{2}{|c|}{ Basis Komoditas } \\
\hline & & & Toga: & $\begin{array}{l}\text { Jahe, kencur, kunyit, } \\
\text { temu lawak, kumis } \\
\text { kucing }\end{array}$ \\
\hline \multirow[t]{5}{*}{2} & \multirow{5}{*}{$\begin{array}{l}\text { Rumah } \\
\text { Tipe } 36 \\
\text { (Luas } \\
\text { tanah } \\
\text { sekitar } 72 \\
\text { m2), } \\
\text { halaman } \\
\text { sempit }\end{array}$} & \multirow[t]{2}{*}{$\begin{array}{l}\text { Vertikultur (model } \\
\text { gantung, tempel, } \\
\text { tegak, rak) }\end{array}$} & Sayuran: & $\begin{array}{l}\text { Sawi, kucai, pakcoi, } \\
\text { kangkung, bayam, } \\
\text { kemangi, caisim, } \\
\text { seledri, selada bokor, } \\
\text { bawang daun }\end{array}$ \\
\hline & & & Toga: & $\begin{array}{l}\text { Kencur, antanan, } \\
\text { gempur batu, daun } \\
\text { jinten, sambiloto, jahe } \\
\text { merah, binahong, } \\
\text { sirih }\end{array}$ \\
\hline & & \multirow[t]{3}{*}{$\begin{array}{l}\text { Pot/polibag } \\
\text { benih/bibit }\end{array}$} & Sayuran: & $\begin{array}{l}\text { Cabai, terong, tomat, } \\
\text { kecipir, kacang } \\
\text { panjang, mentimun, } \\
\text { kenikir, bayam, } \\
\text { kangkung }\end{array}$ \\
\hline & & & Toga: & $\begin{array}{l}\text { Jahe, kencur, kunyit, } \\
\text { sirih hijau/merah, } \\
\text { pegagan, lidah buaya }\end{array}$ \\
\hline & & & Buah: & $\begin{array}{l}\text { jeruk, mangga, jambu, } \\
\text { belimbing }\end{array}$ \\
\hline \multirow[t]{4}{*}{3} & \multirow{4}{*}{$\begin{array}{l}\text { Rumah } \\
\text { Tipe } 45 \\
\text { (Luas } \\
\text { tanah } \\
\text { sekitar } 90 \\
\text { m2), } \\
\text { halaman } \\
\text { sedang }\end{array}$} & \multirow[t]{2}{*}{$\begin{array}{l}\text { Vertikultur (model } \\
\text { gantung, tempel, } \\
\text { tegak, rak) }\end{array}$} & Sayuran: & $\begin{array}{l}\text { Sawi, kucai, pakcoi, } \\
\text { kangkung, bayam, } \\
\text { kemangi, caisim, } \\
\text { seledri, selada bokor }\end{array}$ \\
\hline & & & Toga: & $\begin{array}{l}\text { Kencur, antanan, } \\
\text { gempur batu, daun } \\
\text { jinten, sambiloto, jahe } \\
\text { merah, binahong, } \\
\text { sirih }\end{array}$ \\
\hline & & \multirow[t]{2}{*}{$\begin{array}{l}\text { Pot/polibag } \\
\text { benih/bibit }\end{array}$} & Sayuran: & $\begin{array}{l}\text { Cabai, terong, tomat, } \\
\text { kecipir, kacang } \\
\text { panjang, mentimun, } \\
\text { kenikir, bayam, } \\
\text { kangkung, katuk, } \\
\text { kelor, labu kuning }\end{array}$ \\
\hline & & & Toga: & $\begin{array}{l}\text { Jahe, kencur, kunyit, } \\
\text { kumis kucing, sirih } \\
\text { hijau/merah, pegagan, } \\
\text { lidah buaya, } \\
\text { sambiloto, } \\
\text { temulawak, gempur } \\
\text { batu }\end{array}$ \\
\hline
\end{tabular}




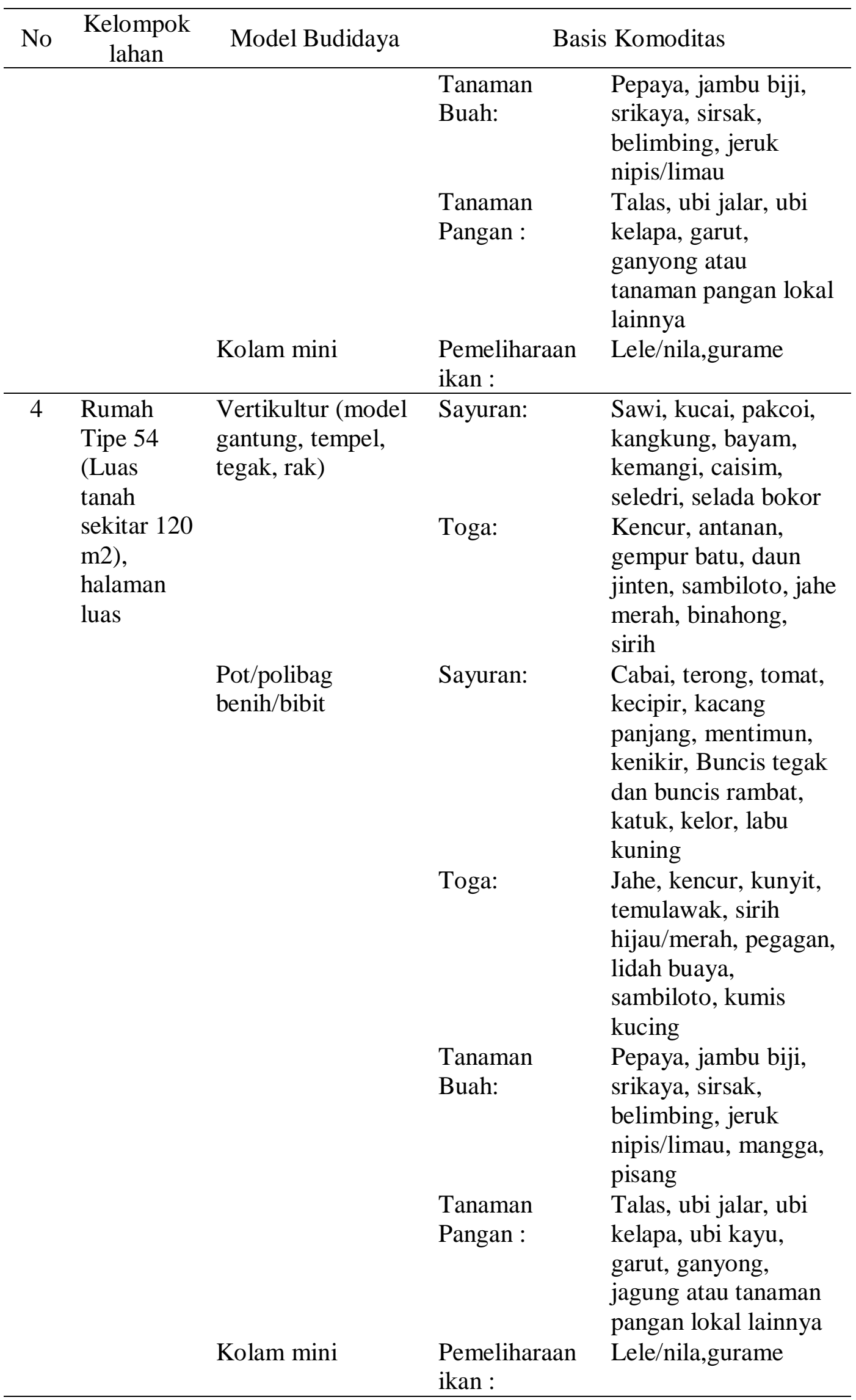




\begin{tabular}{|c|c|c|c|}
\hline No & $\begin{array}{l}\text { Kelompok } \\
\text { lahan }\end{array}$ & Model Budidaya & Basis Komoditas \\
\hline & & $\begin{array}{l}\text { Ternak Unggas } \\
\text { dalam kandang }\end{array}$ & Ayam buras \\
\hline \multirow[t]{3}{*}{5} & $\begin{array}{l}\text { Lahan } \\
\text { terbuka } \\
\text { hijau }\end{array}$ & Tanaman buah & $\begin{array}{l}\text { Mangga, rambutan, pohon salam, } \\
\text { belimbing sayur, tanaman khas daerah/ } \\
\text { tanaman langka }\end{array}$ \\
\hline & & Intensifikasi pagar & $\begin{array}{l}\text { Katuk, daun mangkokan, beluntas, } \\
\text { daun pandan, sereh }\end{array}$ \\
\hline & & $\begin{array}{l}\text { Pelestarian } \\
\text { tanaman pangan }\end{array}$ & aneka umbi, talas, jagung dan serealia \\
\hline 6 & $\begin{array}{l}\text { Kebun } \\
\text { bibit }\end{array}$ & pot, rak, bedengan & Sayuran dan tanaman pangan \\
\hline
\end{tabular}

Sumber : Pedum KRPL, Badan Litbang Pertanian (2011)

KRPL model budidaya rumah tangga beserta jenis komoditasnya di pekarangan pedesaan ditunjukkan pada Tabel 2 .

Tabel 2. Basis komoditas dan contoh model budidaya Rumah Pangan Lestari menurut kelompok pekarangan pedesaan

\begin{tabular}{|c|c|c|c|c|}
\hline \multirow{2}{*}{$\frac{\text { No }}{1}$} & \multirow{2}{*}{$\begin{array}{l}\text { Kelompok } \\
\quad \text { lahan } \\
\text { Pekarangan } \\
\text { sangat sempit } \\
\text { (tanpa } \\
\text { halaman) }\end{array}$} & \multirow{2}{*}{$\begin{array}{l}\text { Model Budidaya } \\
\text { Vertikultur } \\
\text { (model gantung, } \\
\text { tempel, tegak, } \\
\text { rak) }\end{array}$} & \multicolumn{2}{|c|}{ Basis Komoditas } \\
\hline & & & Sayuran: & $\begin{array}{l}\text { Sawi, kucai, pakcoi, } \\
\text { kangkung, bayam, } \\
\text { kemangi, caisim, } \\
\text { seledri, selada bokor, } \\
\text { bawang daun }\end{array}$ \\
\hline & & & Toga: & $\begin{array}{l}\text { Kencur, antanan, } \\
\text { gempur batu, daun } \\
\text { jinten, sambiloto, jahe } \\
\text { merah, binahong, } \\
\text { sirih }\end{array}$ \\
\hline & & $\begin{array}{l}\text { Pot/polibag } \\
\text { benih/bibit }\end{array}$ & Sayuran: & $\begin{array}{l}\text { Cabai, terong, tomat, } \\
\text { mentimun }\end{array}$ \\
\hline & & & Toga: & $\begin{array}{l}\text { Jahe, kencur, kunyit, } \\
\text { temu lawak, kumis } \\
\text { kucing, sirih } \\
\text { hijau/merah, pegagan, } \\
\text { lidah buaya, } \\
\text { sambiloto }\end{array}$ \\
\hline 2 & $\begin{array}{l}\text { Pekarangan } \\
\text { sempit }(<120 \\
\text { m2) }\end{array}$ & $\begin{array}{l}\text { Vertikultur } \\
\text { (model gantung, } \\
\text { tempel, tegak, } \\
\text { rak) }\end{array}$ & Sayuran: & $\begin{array}{l}\text { Sawi, kucai, pakcoi, } \\
\text { kangkung, bayam, } \\
\text { kemangi, caisim, } \\
\text { seledri, selada bokor }\end{array}$ \\
\hline
\end{tabular}




\begin{tabular}{|c|c|c|c|c|}
\hline \multirow[t]{7}{*}{ No } & \multirow[t]{7}{*}{$\begin{array}{l}\text { Kelompok } \\
\text { lahan }\end{array}$} & Model Budidaya & \multicolumn{2}{|c|}{ Basis Komoditas } \\
\hline & & \multirow{4}{*}{$\begin{array}{l}\text { Pot/polibag/tana } \\
\text { m langsung } \\
\text { benih/bibit } \\
\text { pelestarian } \\
\text { tanaman pangan }\end{array}$} & Toga: & $\begin{array}{l}\text { Kencur, antanan, } \\
\text { gempur batu, daun } \\
\text { jinten, sambiloto, jahe } \\
\text { merah, binahong, } \\
\text { sirih }\end{array}$ \\
\hline & & & Sayuran: & $\begin{array}{l}\text { Cabai, kenikir, terong, } \\
\text { tomat, kecipir, kacang } \\
\text { panjang, buncis tegak, } \\
\text { buncis rambat, katuk, } \\
\text { kelor, labu kuning }\end{array}$ \\
\hline & & & Toga: & $\begin{array}{l}\text { Jahe, kencur, kunyit, } \\
\text { temulawak, kumis } \\
\text { kucing, sirih } \\
\text { hijau/merah, pegagan, } \\
\text { lidah buaya, } \\
\text { sambiloto }\end{array}$ \\
\hline & & & Buah: & $\begin{array}{l}\text { pepaya, jeruk nipis, } \\
\text { jambu }\end{array}$ \\
\hline & & \multirow{2}{*}{$\begin{array}{l}\text { Kandang } \\
\text { Kolam Terpal }\end{array}$} & \multicolumn{2}{|c|}{ Ternak ayam buras } \\
\hline & & & \multicolumn{2}{|c|}{ Pemeliharaan ikan : } \\
\hline \multirow[t]{6}{*}{3} & $\begin{array}{l}\text { Pekarangan } \\
\text { sedang (120- } \\
400 \mathrm{~m} 2)\end{array}$ & $\begin{array}{l}\text { Pot/polibag/tana } \\
\text { m langsung }\end{array}$ & Sayuran: & $\begin{array}{l}\text { Cabai, Sawi, kenikir, } \\
\text { terong, tomat, bayam, } \\
\text { kangkung, kacang } \\
\text { panjang, } \\
\text { kecipir,katuk, kelor, } \\
\text { labu kuning }\end{array}$ \\
\hline & & & Toga: & $\begin{array}{l}\text { jahe, kencur, } \\
\text { lengkuas, kunyit, } \\
\text { temulawak, sirih }\end{array}$ \\
\hline & & Kandang & $\begin{array}{l}\text { Ternak kamb } \\
\text { ayam buras }\end{array}$ & g, domba dan/atau \\
\hline & & Kolam & $\begin{array}{l}\text { Pemeliharaa } \\
\text { n ikan : }\end{array}$ & Lele/nila,gurame \\
\hline & & $\begin{array}{l}\text { Bedengan, } \\
\text { Surjan, } \\
\text { multistrata }\end{array}$ & $\begin{array}{l}\text { intensifikasi } \\
\text { pekarangan }\end{array}$ & $\begin{array}{l}\text { sayuran/buah/umbi/ka } \\
\text { cang-kacangan }\end{array}$ \\
\hline & & Multistrata & $\begin{array}{l}\text { intensifikasi } \\
\text { pagar }\end{array}$ & $\begin{array}{l}\text { Kaliandra, dadap, } \\
\text { gliriside, rumput, } \\
\text { garut, talas, pisang, } \\
\text { nenas, melinjo, katuk, } \\
\text { kelor, labu kuning, } \\
\text { ganyong }\end{array}$ \\
\hline
\end{tabular}




\begin{tabular}{|c|c|c|c|c|}
\hline No & $\begin{array}{l}\text { Kelompok } \\
\text { lahan }\end{array}$ & Model Budidaya & \multicolumn{2}{|c|}{ Basis Komoditas } \\
\hline \multirow[t]{6}{*}{4} & $\begin{array}{l}\text { Pekarangan } \\
\text { luas (> } 400 \\
\text { m2) }\end{array}$ & $\begin{array}{l}\text { Pot/polibag/tana } \\
\text { m langsung }\end{array}$ & Toga: & $\begin{array}{l}\text { Cabai, Sawi, kenikir, } \\
\text { terong, tomat, bayam, } \\
\text { kangkung, kacang } \\
\text { panjang, } \\
\text { kecipir,buncis tegak } \\
\text { dan rambat, katuk, } \\
\text { kelor, labu kuning } \\
\text { jahe, kencur, } \\
\text { lengkuas, kunyit, } \\
\text { temulawak, sirih, } \\
\text { lidah buaya }\end{array}$ \\
\hline & & Kandang & $\begin{array}{l}\text { Ternak kambi } \\
\text { ayam buras }\end{array}$ & g, domba dan/atau \\
\hline & & Kolam & $\begin{array}{l}\text { Pemeliharaa } \\
\text { n ikan : }\end{array}$ & Lele/nila,gurame \\
\hline & & $\begin{array}{l}\text { Bedengan, } \\
\text { Surjan, } \\
\text { multistrata }\end{array}$ & $\begin{array}{l}\text { intensifikasi } \\
\text { pekarangan }\end{array}$ & $\begin{array}{l}\text { sayuran/buah/umbi/ka } \\
\text { cang-kacangan }\end{array}$ \\
\hline & & Benih/bibit & Sayuran dan $t$ & anaman pangan \\
\hline & & Multistrata & $\begin{array}{l}\text { intensifikasi } \\
\text { pagar }\end{array}$ & $\begin{array}{l}\text { Kaliandra, dadap, } \\
\text { gliriside, rumput, } \\
\text { garut, talas, pisang, } \\
\text { nenas, melinjo, } \\
\text { ganyong, katuk, } \\
\text { kelor,labu kuning }\end{array}$ \\
\hline 5 & $\begin{array}{l}\text { Intensifikasi } \\
\text { pagar jalan }\end{array}$ & Multistrata & \multicolumn{2}{|c|}{$\begin{array}{l}\text { Tanaman buah, tanaman hijauan } \\
\text { pakan ternak }\end{array}$} \\
\hline 6 & $\begin{array}{l}\text { Intensifikasi } \\
\text { halaman } \\
\text { kantor desa, } \\
\text { sekolah, dan } \\
\text { fasilitas umum } \\
\text { lainnya }\end{array}$ & $\begin{array}{l}\text { pot, bedengan, } \\
\text { tanam langsung }\end{array}$ & \multicolumn{2}{|c|}{$\begin{array}{l}\text { Tanaman sayuran, buah, pagar } \\
\text { multistrata }\end{array}$} \\
\hline
\end{tabular}

Sumber : Pedum KRPL, Badan Litbang Pertanian (2011)

Kegiatan pola pemanfaatan pekarangan ini, sebenarnya sudah lama dilakukan di daerah di pulau Jawa dengan budaya bercocok tanamanya di sekitar rumahnya. Kegiatan bercocok tanam ini adalah menanam tanaman dengan strata yang berbeda, yaitu strata pohon (tanaman tahunan), tanaman semusim (tanaman pangan), dan tanaman rumput (tanaman pakan ternak). Kegiatan bercocok tanam yang seperti ini disebut dengan tipe pola wana tani (agroforestry) atau disebut juga dengan istilah kebun campuran. Dengan adanya KRPL, daerah yang menjadi 
percontohan dalam kegiatan KRPL ini adalah Dusun Jelok, Desa Kayen, Kecamatan Pacitan, Kabupaten Pacitan, Jawa Timur yang dimulai dari Februari 2011. Program ini pada tahun tersebut melibatkan 36 KK yang tersebar dalam 2 RT (Ashari et. al., 2012).

Pedoman yang ada di KRPL ini tidak bersifat mengikat. Maksudnya adalah masyarakat bebas untuk mengelola pekarangannya dengan menanam komoditas sesuai dengan kebutuhan dari keluarganya masing-masing. Selain itu, masyarakat biasa menanam suatu tanaman dengan melihat cocok atau tidaknya suatu tanaman ditanam di tanah tersebut. Suatu tanaman yang tidak mampu tumbuh di suatu tempat, jika tetap ditanam tentunya tidak akan menghasilkan hasil yang optimal.

Pelaksanaan KRPL ini dapat dilakukan oleh individu maupun sekelompok masyarakat yang tergabung dalam suatu perkumpulan. Pelibatan banyak pihak dalam suatu kelompok dalam pelaksanaan KRPL akan dapat menunjang keberhasilan dari KRPL di lokasi tersebut. Pemanfaatan pekarangan secara sederhana dapat dilakukan masyarakat sendiri. Langkah-langkah dalam pemanfaatan pekarangan diuraikan sebagai berikut:

\section{Persiapan media tanam}

Penggunaan media tanam dilakukan paling awal sebelum kegiatan penanaman dilakukan. Kegiatan persiapan media tanam yang dilakukan pada sebidang lahan dapat dilakukan dengan cara membersihkan lahan dari gulma. Jika sistem yang digunakan adalah sistem konservasi, tentunya yang dibersihkan gulmanya hanya lokasi yang akan ditanami saja, sedangkan tanah yang tidak ditanami dibiarkan gulma tetap ada dan hanya dilakukan kegiatan pengendalian saja. Jika dilakukan sistem konvensional gulma dibersihkan semua dari semua lahannya. Tanah yang telah dibersihkan gulma nya selanjutnya dilakukan pencampuran tanah dengan kompos ataupun kontoran ternak untuk menambah hara. Kegiatan persiapan media tanam yang dilakukan dengan metode penanaman di dalam pot/polibag dapat dilakukan dengan menyiapkan media tanam bisa dengan campuran tanah, kotoran ternak/kompos ataupun dengan sekam, kemudian bahanbahan tersebut dimasukkan ke dalam pot/polibag. 


\section{Pemilihan jenis tanaman}

Pemilihan jenis tanaman ini dilakukan berdasarkan keperluan dan kepentingan dari keluarga tersebut. Tanaman yang akan ditanam tentunya harus bervariasi dan bertujuan memenuhi keperluan rumah tangga terlebih dahulu. Jika terdapat kelebihan hasil, dapat dilakukan penjualan yang dapat menambah pendapatan keluarga. Jenis tanaman yang bisa ditanam adalah tanaman untuk keperluan dapur (cabai, tomat, sereh, dll), tanaman sayur (kangkung, kacang panjang, dll), tanaman obat (jahe, kunyit, kencur, dll), tanaman buah (pepaya, belimbing, mangga, dll), maupun tanaman tahunan yang bermanfaat (cengkeh, jati, sengon, dll).

\section{Pengaturan tata letak tanaman}

Tata letak tanaman ini berhubungan dengan kondisi paparan matahari. Tanaman tentunya membutuhkan sinar matahari untuk pertumbuhannya. Tata letak tanaman yang dapat dilakukan adalah dengan menanam tanaman yang berukuran kecil di sebelah timur, sedangkan tanaman tinggi di sebelah barat. Selain itu, pengaturan juga dapat dilakukan dengan sistem strata bercampur dimana tanaman berukuran kecil dan berukuran tinggi ditanam berdekatan dengan syarat tanaman kecil besar tidak menghambat tanaman kecil untuk mendapatkan sinar matahari yang cukup.

\section{Kegiatan pemeliharaan}

Kegiatan pemeliharaan yang dapat dilakukan adalah penyiraman, pemupukan, penyulaman, pengendalian hama dan penyakit serta gulma. Penyiraman atau pengairan dapat dilakukan dengan cara menggunakan air sisa atau air yang berasal dari kolam. Pemupukan dapat dilakukan dengan menggunakan pupuk anorganik (urea, $\mathrm{KCl}$, dll) maupun pupuk organik (pupuk kandang ataupun kompos). Penyulaman dilakukan hanya jika tanaman di petak tanaman atau di dalam pot/polibag tidak tumbuh atau terserang penyakit/hama. Penyulaman bisa tidak dilakukan, tetapi mengganti dengan tanaman lain. Pengendalian gulma dapat dilakukan dengan cara manual (cabut langsung), sedangkan pengendalian hama dan penyakit dapat dilakukan dengan sistem pengendalian hama dan penyakit secara terpadu. 


\section{KESIMPULAN}

Kegiatan optimalisasi pekarangan merupakan salah satu kegiatan yang dapat dilakukan di masa pandemic COVID-19 untuk mencegah terjadinya krisis pangan. Kegiatan optimalisasi pekarangan dapat dilakukan dengan cara mengikuti metode KRPL ataupun menggunakan cara tradisional.

\section{DAFTAR PUSTAKA}

Affandi. 2002. Homme Garden: Sebagai Salah Satu Sistem Agroforestry Lokal. Medan: USU digital library.

Ashari, Saptana, Purwantini, T.B. 2012. Potensi dan Prospek Pemanfaatan Lahan Pekarangan untuk mendukung ketahanan pangan. Forum Penelitian Agro Ekonomi. 30 (1): 13-30.

Badan Litbang Pertanian. 2011. Pedoman Umum Model Kawasan Rumah Pangan Lestari Badan Penelitian dan Pengembangan Pertanian. Jakarta.

Baskara, B. 2020. Rangkaian peristiwa pertama COVID-19. https://bebas.kompas.id/baca/riset/2020/04/18/rangkaian-peristiwa-pertamacovid-19/. Diakses pada 19 Mei 2020.

Gugus Tugas Percepatan Penanganan COVID-19. 2020. Data Sebaran. https://covid19.go.id/. Diakses pada 19 Mei 2020.

Heldavidson. 2020. First Covid-19 case happened in November, China government records show https://www.theguardian.com/world/2020/mar/13/first-covid-19-casehappened-in-november-china-government-records-show-report. Diakses pada 20 Mei 2020.

Irwan, S.N.R., Rogomulyo, R., Trisnowati, S. 2018. Pemanfaatan pekarangan melalui pengembangan lanskap produktif di Desa Mangunan, Kabupaten Bantul Yogyakarta. Jurnal Ilmu Pertanian Indonesia (JIPI) 23(2): 148-157.

Jayani, D.H. 2020. Krisis Pangan akibat COVID-19. https://katadata.co.id/infografik/2020/05/07/krisis-pangan-akibat-covid-19. Diakses pada 20 Mei 2020.

Khudori. 2020. Perang Lawan Corona dan Benteng Terakhir Krisis Pangan. https://www.cnnindonesia.com/ekonomi/20200503093852-93499500/perang-lawan-corona-dan-benteng-terakhir-krisis-pangan. Diakses pada 20 Mei 2020. 
Ramadayanti, E. 2020. Covid-19 dalam Perspektif One Health Approach dan Law Enforcement. http://fh.unpad.ac.id/covid-19-dalam-perspektif-one-healthapproach-dan-law-enforcement/\#_ftn4. Diakses pada 19 Mei 2020.

Safrizal, Putra, I.P., Sofyan, S., dan Bimo. 2020. Pedoman umum menghadapi Pandemi COVID-19 Bagi Pemerintah Daerah. Pencegahan, Pengendalian, Diagnosis dan Manajemen. Jakarta : Kementerian Dalam Negeri.

Soemarwoto, O. 1981. Sistem Kebun-Talun: Suatu Sistem Pertanian Hutan Tradisional. Prosiding Seminar Agroforetry dan Pengendalian Perladangan. 19-21 November 1981. Jakarta.

World Health Organization (WHO). 2020. WHO Coronavirus Disease (COVID19) Dashboard. https://covid19.who.int/. Diakses pada 19 Mei 2020.

World Health Organization (WHO). 2020. Global surveillance for human infection with novel coronavirus (2019-ncov). https://www.who.int/publications-detail/global-surveillance-for-humaninfection-with-novel-coronavirus-(2019-ncov). Diakses pada 19 Mei 2020. 